\title{
Ecology of aerobic anoxygenic phototrophic bacteria along an oligotrophic gradient in the Mediterranean Sea
}

\author{
D. Lamy ${ }^{1,2, *}$, C. Jeanthon ${ }^{3,4}$, M. T. Cottrell ${ }^{5}$, D. L. Kirchman ${ }^{5}$, F. Van Wambeke ${ }^{6}$, J. Ras ${ }^{7}$, O. Dahan ${ }^{3,4}$, \\ M. Pujo-Pay ${ }^{1,2}$, L. Oriol ${ }^{1,2}$, L. Bariat ${ }^{2,8}$, P. Catala ${ }^{1,2}$, V. Cornet-Barthaux ${ }^{9}$, and P. Lebaron ${ }^{1,2}$ \\ ${ }^{1}$ INSU-CNRS, UMR 7621, Laboratoire d'Océanographie Microbienne, LOMIC, Observatoire Océanologique de Banyuls, \\ 66651 Banyuls-sur-mer, France \\ ${ }^{2}$ UPMC Univ Paris 06, Observatoire Océanologique de Banyuls, 66651 Banyuls-sur-mer, France \\ ${ }^{3}$ UPMC Univ Paris 06, UMR 7144, Adaptation et Diversité en Milieu Marin, Station Biologique de Roscoff, \\ 29680 Roscoff, France \\ ${ }^{4}$ INSU-CNRS, Observatoire Océanologique, UMR 7144, Groupe Plancton Océanique, Station Biologique, \\ 29680 Roscoff, France \\ ${ }^{5}$ School of Marine Science and Policy, University of Delaware, Lewes, Delaware 19958, USA \\ ${ }^{6}$ INSU-CNRS, Université de la Méditerranée, UMR 6117, LMGEM, Laboratoire de Microbiologie, Géochimie et Ecologie \\ Marines, Centre d'Océanologie de Marseille, Campus de Luminy, Case 901, 13288 Marseille cedex 9, France \\ ${ }^{7}$ Laboratoire d'Océanographie de Villefranche-sur-mer, UMR 7093, CNRS, Université Pierre et Marie Curie, \\ Villefranche-sur-mer Cedex, France \\ ${ }^{8}$ CNRS, UMS 2348, Observatoire Océanologique de Banyuls, 66651 Banyuls-sur-mer, France \\ ${ }^{9}$ Laboratoire d'Océanographie Physique et Biogéochimique (LOPB), UMR 6535, CNRS-IRD-Université de la Méditerranée, \\ Centre d'Océanologie de Marseille, Campus de Luminy, Case 901, 13288 Cedex 09 Marseille, France \\ * present address: University of Vienna, Department of Marine Biology, Althanstrasse 14, 1090 Vienna, Austria
}

Received: 16 December 2010 - Published in Biogeosciences Discuss.: 12 January 2011

Revised: 12 April 2011 - Accepted: 13 April 2011 - Published: 20 April 2011

\begin{abstract}
Aerobic anoxygenic phototrophic (AAP) bacteria are photoheterotrophic prokaryotes able to use both light and organic substrates for energy production. They are widely distributed in coastal and oceanic environments and may contribute significantly to the carbon cycle in the upper ocean. To better understand questions regarding links between the ecology of these photoheterotrophic bacteria and the trophic status of water masses, we examined their horizontal and vertical distribution and the effects of nutrient additions on their growth along an oligotrophic gradient in the Mediterranean Sea. Concentrations of bacteriochlorophyll- $a$ (BChl- $a$ ) and AAP bacterial abundance decreased from the western to the eastern basin of the Mediterranean Sea and were linked with concentrations of chlorophyll- $a$, nutrient and dissolved organic carbon. Inorganic nutrient and glucose additions to surface seawater samples along the oligotrophic gradient revealed that AAP bacteria were nitrogen- and carbon-limited in the ultraoligotrophic eastern basin. The intensity of the
\end{abstract}

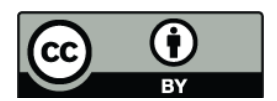

Correspondence to: D. Lamy

(lamyd2@univie.ac.at)
AAP bacterial growth response generally differed from that of the total bacterial growth response. BChl- $a$ quota of AAP bacterial communities was significantly higher in the eastern basin than in the western basin, suggesting that reliance on phototrophy varied along the oligotrophic gradient and that nutrient and/or carbon limitation favors BChl- $a$ synthesis.

\section{Introduction}

Aerobic anoxygenic phototrophic (AAP) bacteria are photoheterotrophic prokaryotes able to combine light and dissolved organic matter as energy sources (Beatty, 2002; Suzuki and Béjà, 2007; Yurkov and Beatty, 1998). Their primary light harvesting pigment is bacteriochlorophyll- $a$ (BChl-a) (Koblížek et al., 2005; Kolber et al., 2001) and they depend on oxygen and organic carbon for energy. These bacteria are widely distributed in marine environments and their abundances vary greatly, accounting for up to $25 \%$ of the bacterial abundance (Cottrell and Kirchman, 2009; Lami et al., 2007; Salka et al., 2008; Schwalbach and Fuhrman,

Published by Copernicus Publications on behalf of the European Geosciences Union. 
2005). The metabolic flexibility, fast growth, high abundance and widespread occurrence of these organisms in both marine and freshwater environments challenge our view of carbon and energy budgets (Eiler, 2006; Lamy et al., 2011; Mašín et al., 2008; Moran and Miller, 2007) and suggest that AAP bacteria play a significant role in aquatic food webs and biogeochemical cycles (Koblížek et al., 2007; Kolber et al., 2001).

An initial hypothesis regarding AAP bacteria distribution was that photoheterotrophy would be beneficial in nutrientpoor environments, such as oligotrophic zones (Karl, 2002; Kolber et al., 2000). In contrast, various reports showed that these organisms are abundant in eutrophic as well as in oligotrophic environments (Jiao et al., 2007; Koblížek et al., 2006; Yutin et al., 2007). Other authors suggested that nutrient concentrations (Mašín et al., 2008), attachment to particles (Cottrell et al., 2010; Waidner and Kirchman, 2007) or light intensity (Koblížek et al., 2003; Shiba, 1991) may influence AAP bacterial abundance.

Increasing attention has been paid to AAP bacteria in marine environments exhibiting various trophic regimes. However, oligotrophic waters, which represent $60 \%$ of the surface of the oceans, have not been extensively studied. The Mediterranean Sea has a wide range of oligotrophic conditions including extreme oligotrophy in summer when the water column is stratified (Berman et al., 1985). The Mediterranean Sea is known to have low nutrient concentrations, especially phosphate (Moutin and Raimbault, 2002), making it one of the largest nutrient-depleted areas in the world (Ignatiades, 2005). Overall, the Mediterranean Sea could serve as a particularly relevant system to follow the spatial distribution of AAP bacteria and to examine the environmental factors that are hypothesized to influence their distribution. A few studies examined the large diversity of AAP bacteria in the Mediterranean Sea (Lehours et al., 2010; Oz et al., 2005; Yutin and Béjà, 2005; Yutin et al., 2008). However, their quantitative variation with longitude and depth has never been explored in this area.

The objectives of this study were to determine the vertical and longitudinal distribution of AAP bacteria in the Mediterranean Sea and to identify the factors limiting their growth across a wide longitudinal gradient of oligotrophy. We examined these variables along a $3000 \mathrm{~km}$ transect from the west to the east during the BOUM cruise carried out in JuneJuly 2008. The abundance and distribution of AAP bacteria were monitored using infra-red (IR) kinetic fluorometry, high performance liquid chromatography (HPLC) and IR epifluorescence microscopy. The effects of inorganic nitrogen, phosphate and glucose additions on AAP and total bacterial growth were studied in surface seawater samples incubated under natural solar irradiance. In a companion paper, Jeanthon et al. (2011) reported the isolation of AAP bacteria and unveiled the diversity of the active AAP populations retrieved during the BOUM cruise. Our study showed that AAP bacteria decreased in abundance from the oligotrophic western

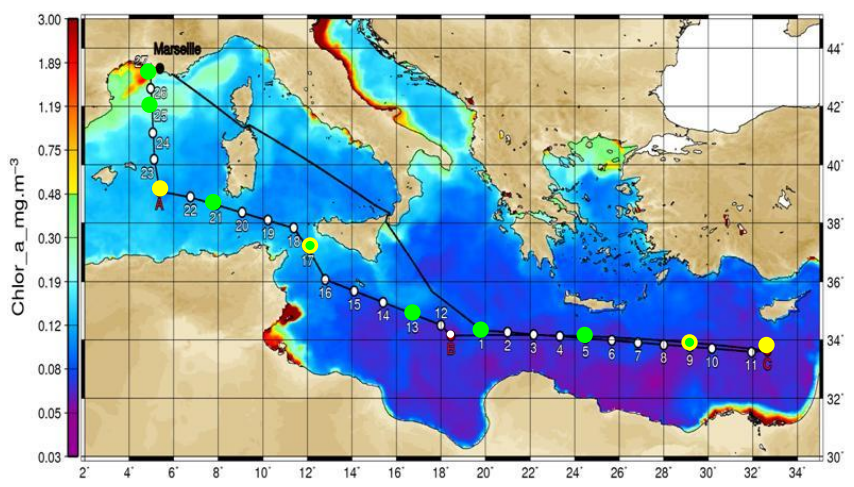

Fig. 1. Transect of the BOUM cruise (16 June-20 July 2008) superimposed on a SeaWiFS composite image of the sea surface chlorophyll- $a$ concentrations (June 2008, courtesy to E. Bosc) and location of the 30 sampled stations. The bacteriochlorophyll- $a$ (BChl- $a$ ) concentration was assessed at all the stations. The AAP bacterial abundance and the BChl- $a$ fluorescence were measured on 8 stations (green dots, stations $27,25,21,17,13,1,5$ and 9). The experiments conducted on the effect of nutrient amendments on AAP bacterial growth were done on 4 stations (yellow dots, stations A, 17, 9 and C).

to the ultra-oligotrophic eastern basins of the Mediterranean Sea. The higher concentrations of BChl- $a$ per-cell in the eastern part of the Mediterranean Sea suggest that photosynthetic pigment synthesis by AAP bacteria may be favored in nutrient-depleted conditions.

\section{Material and methods}

\subsection{Study area and sampling}

Sampling was carried out during the "Biogeochemistry from the Oligotrophic to the Ultra-oligotrophic Mediterranean Sea" (BOUM) cruise on the R/V L'Atalante during JuneJuly 2008. The cruise was planned as a $3000 \mathrm{~km}$ transect of stations encompassing a large longitudinal gradient in the Mediterranean Sea (Fig. 1, see also Moutin et al., 2011). Hydrological, biological and chemical parameters were studied at 27 short-term stations and three long-term stations designed by letters (A, B, and C), located at the centre of anticyclonic gyres, where lateral advection was expected to be minimum (Fig. 1). The east-to-west transect crossed the 3 main areas of the Mediterranean Sea, the western (stations 18 to 27), the Ionian (station 2 to 17) and the eastern or Levantine basins (stations 3 to $\mathrm{C}$ ).

\subsection{Environmental parameters}

Profiles of temperature, salinity and photosynthetically active radiation (PAR) were measured with a SBE 911 PLUS Conductivity-Temperature-Depth (CTD) system. Nutrients concentrations were determined with a Skalar Autoanalyzer 
(Skalar Analytical B. V., The Netherlands) according to Wood et al. (1967) and Bendschneider and Robinson (1952) for nitrate $\left(\mathrm{NO}_{3}\right)$ and nitrite $\left(\mathrm{NO}_{2}\right)$ concentrations and according to Murphy and Riley (1962) for phosphate $\left(\mathrm{PO}_{4}\right)$ concentrations. Protocols were adapted to the Skalar Autoanalyser from Tréguer and Le Corre (1975). Soluble reactive phosphorus was also quantified (Rimmelin and Moutin, 2005) based on the MAGIC method (Karl and Tien, 1992). Ammonium $\left(\mathrm{NH}_{4}\right)$ concentrations were determined onboard by fluorometry according to Holmes et al. (1999) on a Jasco FP-2020 fluorometer.

Concentration of dissolved organic carbon (DOC) was measured on a model TOC-V analyzer (Shimadzu, Japan) (Benner and Strom, 1993). Dissolved organic nitrogen (DON) and phosphate (DOP) were analyzed by persulfate wet-oxidation according to Pujo-Pay et al. (1997). Particulate organic carbon (POC) was quantified using a model CHN 2400 analyzer (Perkin Elmer 2400, Waltham, MA) following Pregl (1937) and Sharp (1974). Particulate organic nitrogen (PON) and phosphate (POP) were analyzed simultaneously on board according to the wet oxidation procedure of Pujo-Pay and Raimbault (1994). The methods conducted for the determination of the nutrients and dissolved and particulate matter concentrations are described in Pujo-Pay et al. (2011).

\subsection{AAP bacterial abundance}

Water samples for the determination of AAP bacterial abundance were taken at 5-6 depths from 8 stations $(27,25$, $21,17,13,1,5$ and 9) equally distributed in the 3 different basins. Samples were preserved with $2 \%$ paraformaldehyde for $1-4 \mathrm{~h}$ at $4{ }^{\circ} \mathrm{C}$ in the dark and filtered onto 0.2 $\mu \mathrm{m}$-pore-size black polycarbonate filters. The filters were quickly frozen in liquid nitrogen and stored at $-80^{\circ} \mathrm{C}$ until processing. Samples were processed as described previously (Cottrell et al., 2006). Briefly, each filter was stained with $4^{\prime}$,6-diamidino-2-phenylindole (DAPI, $1 \mu \mathrm{g} \mathrm{ml}^{-1}$ final concentration) in $1 \times$ phosphate-buffered saline for $10 \mathrm{~min}$. Stained samples were counted immediately. AAP cells were counted using an Olympus Provis AX 70 microscope and image analysis software (ImagePro Plus, Media Cybernetics) to identify cells having DAPI and IR fluorescence but not chlorophyll- $a$ (Chl- $a$ ) or phycoerythrin (PE) fluorescence. Twenty images per sample were captured using a chargecoupled-device camera (Intensified Retiga Extended Blue; QImaging, Surrey, BC) with the following exposure times: DAPI, $160 \mathrm{~ms}$; IR, $400 \mathrm{~ms}$; Chl- $a, 1500 \mathrm{~ms}$; PE, $50 \mathrm{~ms}$. The biovolumes of total bacteria and AAP bacteria were compared using cell sizes obtained by image analysis (Cottrell et al., 2006).

\subsection{Fluorometry}

BChl- $a$ fluorescence was measured at the same stations and depths as those sampled for AAP bacterial abundance. BChl$a$ fluorescence was determined using an IR kinetic fluorometer using the method previously described (Koblížek et al., 2005). Briefly, the instrument consisted of a standard PSI fluorometer control unit (FL200/PS, Photon Systems Instruments, Brno, Czechia) and custom-made optics (Koblížek et al., 2005). The absolute detection limit was $0.2 \mathrm{ng} \mathrm{BChl}-a 1^{-1}$ (Koblížek et al., 2007). To discriminate between the Chl- $a$ and BChl- $a$ contribution in the IR fluorescence $(>850 \mathrm{~nm})$, phytoplankton fluorescence was selectively inhibited by adding $10^{-5} \mathrm{M}$ (final concentration) of 3-(3,4-dichlorophenyl)-1,1-dimethylurea (Diuron, PESTANAL, Fluka), which specifically inhibits Photosystem II of oxygenic phototrophs but does not affect the reaction centers of AAP bacteria. The variable part of the kinetic IR signal originating from AAP bacterial reaction centers was then determined (Koblížek et al., 2005). This approach avoids potential interferences from other fluorescing compounds not exhibiting variable fluorescence or from electrical drifts within the detection system that occur on different time scales. Size fractionation (Lami et al., 2009), was conducted at the same stations and at the depths of maximum BChl- $a$ fluorescence. Briefly, for each sample, $<0.8 \mu \mathrm{m}$ and $<3 \mu \mathrm{m}$ $\mathrm{BChl}-a$ fluorescence signals were recorded along with the original whole water sample and the percentage of BChl- $a$ fluorescence in individual fractions was calculated. Gravity filtration was used to minimize potential particle dislodging by filtration (Waidner and Kirchman, 2007).

\subsection{Bacterioplankton abundance and heterotrophic prokaryotic production}

The abundances of total heterotrophic prokaryotes (including AAP bacteria) and autotrophic prokaryotes (Synechococcus and Prochlorococcus) were measured by flow cytometry using a FACSCalibur flow cytometer (Becton Dickinson, San Jose, CA) according to Marie et al. (2002). The bacterial production was determined by $\left[{ }^{3} \mathrm{H}\right]$-leucine incorporation applying the centrifugation method (Smith and Azam, 1992) and is detailed in Van Wambeke et al. (2010). Production by Archaea would be included in this measurement, but their abundance is low in Mediterranean surface waters (De Corte et al., 2009), particularly during the stratification period (Winter et al., 2009).

\subsection{Pigment concentrations}

Samples for the determination of the pigment concentrations were collected at the 30 stations at $7-12$ depths. Seawater sample (1 to 2.51 ) was filtered onto a stack of two GF/F Whatman filters which were frozen immediately in liquid nitrogen and then stored at $-80^{\circ} \mathrm{C}$ until analysis as 
previously described (Ras et al., 2008). Briefly, the samples were extracted in $3 \mathrm{ml}$ of methanol for at least one hour and the clarified extracts were injected into a 1100 series high-performance liquid chromatography system (Agilent Technologies) according to a modified version of the method described by Van Heukelem and Thomas (2001). Separation was achieved during a gradient elution between a tetrabutylammonium acetate-methanol mixture (30:70) and $100 \%$ methanol. Chl- $a$ and divinyl-Chl- $a$ (Div-Chl- $a$ ) were detected at $667 \mathrm{~nm}$ and BChl- $a$ at $770 \mathrm{~nm}$ using a diode array detector. The detection limit was $0.1 \mathrm{ng} \mathrm{l}^{-1}$ and the injection precision was $0.4 \%$. The different pigments were identified both by their retention times and by absorption spectra.

\subsection{Effects of nutrient and glucose amendments on bacterial production and growth of AAP and total prokaryotes}

To identify the factors limiting heterotrophic bacterial production and cell growth of AAP bacteria and total prokaryotes, on board enrichments were conducted. Selected surface seawater samples (3-5 m depth) were collected and dispensed into acid-washed transparent polycarbonate flasks ( $250 \mathrm{ml}$, Nalgene). Nutrients were added to unfiltered seawater samples in order to obtain a final concentration of $1 \mu \mathrm{MNH} \mathrm{H}_{4} \mathrm{Cl}+1 \mu \mathrm{M} \mathrm{NaNO}_{3}(\mathrm{~N}), 0.25 \mu \mathrm{MNa}_{2} \mathrm{HPO}_{4}(\mathrm{P})$, and $10 \mu \mathrm{M} \mathrm{C}$-glucose (C). For these experiments, a series of five flasks (control, $+\mathrm{P},+\mathrm{N},+\mathrm{C},+\mathrm{NPC}$ ) were incubated for $48 \mathrm{~h}$ under simulated in situ conditions, in on-deck incubators with running surface seawater and neutral density screens to mimic in situ 55\% light conditions. After incubation, samples for determining the abundance and growth of AAP bacteria and total prokaryotes and for measuring bacterial production were processed as described above.

\subsection{Statistical analyses}

A redundancy analysis (RDA) was used to determine which environmental variables were the most significant to explain variation in the abundance of autotrophic (Synechococcus and Prochlorococcus), photoheterotrophic (AAP) and total prokaryotes. We assumed a linear response of cyanobacteria, AAP bacteria and total prokaryotes to environmental variations since the gradient length, expressed as standard deviation units of species turnover (SD) along the first ordination axis and determined through a detrended canonical correspondence analysis along the first ordination axis, was $<1 \mathrm{SD}$. The gradient length is a measure of how unimodal or linear the species responses are along an ordination axis and a gradient length under 1 SD would indicate a clear linear response of the species along this gradient (Ramette, 2007; ter Braak and Smilauer, 2002). The null hypothesis that the cyanobacterial and bacterial abundances were independent of the environmental parameters was tested using constrained ordination with a Monte Carlo permutation test (499 permu-

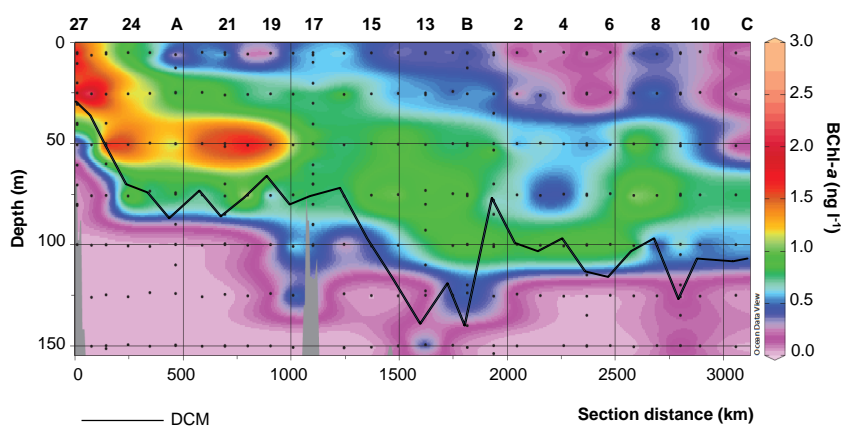

Fig. 2. Longitudinal cross section of BChl- $a$ concentration along the BOUM transect, from the most north-western station (left) to the most eastern station (right) and for the $0-150 \mathrm{~m}$ layer. Depth of the deep chlorophyll maximum (DCM) is also indicated (black line).

tations). Temperature, salinity, depth, concentrations of Chl$a$, nutrients and organic matter concentrations (DOC, DOP, DON and POC) and PAR were used as explanatory variables. The RDA analysis was performed using the CANOCO version 4.5 software (ter Braak, 1989).

Spearman correlations were performed to identify the significant links within the BChl- $a$-related parameters. Multiple regression analysis was performed to determine which proportion of the variation in AAP bacterial abundance could be explained by the variation in environmental parameters, used as explanatory variables. A multiple stepwise regression with forward selection was performed to identify major environmental or extrinsic factors controlling the variation of AAP cell abundances. Since the variables were not normally distributed (Shapiro-Wilk test, $p>0.05$ ), dependent and independent variables were log-transformed to meet the assumption of normality. The explanatory variables were the same as those used in the RDA analysis. An ANOVA analysis followed by a LSD pairwise-comparison test was performed to compare BChl- $a$ quotas along the transect. The correlation, regression and ANOVA analyses were performed using the XLSTAT 7.5.3 package.

\section{Results}

\subsection{Environmental setting}

The physical and hydrologic characteristics of the water masses in the Mediterranean Sea have been previously described and full details for the BOUM cruise can be found in Moutin et al. (2011). During the summer BOUM cruise, surface seawater temperatures ranged from $24^{\circ} \mathrm{C}$ in the western basin (station A) to $27.5^{\circ} \mathrm{C}$ in the central-eastern part (station B). Depth distributions of Chl- $a$ concentrations included a well defined deep chlorophyll maximum (DCM), more pronounced in the western basin, and deepening from west ( $\sim 40$ to $80 \mathrm{~m}$ ) to east (from 80 to $>100 \mathrm{~m}$ ) (Fig. 2; see 
also Crombet et al., 2011). Surface Mediterranean waters were depleted in nutrients and the thickness of this depleted layer increased towards the east from about $10 \mathrm{~m}$ in the Gulf of Lion to more than $100 \mathrm{~m}$ in the Levantine basin (for details see Pujo-Pay et al., 2011).

\subsection{Abundance and size fractionation of AAP bacteria along the BOUM transect}

Concentrations of BChl- $a$ ranged between undetectable levels and $3.1 \mathrm{ng}^{-1}$, averaging $0.4 \pm 0.5 \mathrm{ng}^{-1}$ between 0 and $150 \mathrm{~m}$ (Fig. 2). The concentrations decreased from west to east, with maximum values (from 1.1 to $3.1 \mathrm{ng} \mathrm{l}^{-1}$ ) measured in the Rhône River plume toward the western basin (until station 19) at depths comprised between 5 and $60 \mathrm{~m}$. The maximum values of BChl- $a$ concentrations deepened toward the east, following the deepening of the DCM. The BChl- $a$ concentrations were low $\left(<0.5 \mathrm{ngl}^{-1}\right)$ below the DCM. In the Ionian and eastern basins, highest BChl- $a$ values (0.7$1.0 \mathrm{ng}^{-1}$ ) occurred at depths between 25 and $100 \mathrm{~m}$, and concentrations were low $\left(<0.5 \mathrm{ng} \mathrm{l}^{-1}\right)$ in subsurface waters.

At eight stations equally distributed along the transect, AAP bacteria were investigated by measuring BChl- $a$ concentrations, BChl- $a$ fluorescence and AAP bacterial abundance (Fig. 3a). The three AAP bacterial parameters clearly showed similar longitudinal and vertical patterns, demonstrating that AAP bacteria were mostly found in the euphotic zone along the whole transect. The BChl- $a$ concentrations were significantly and positively correlated with the AAP bacterial abundance (Spearman correlation, $r=0.61, n=60$, $p<0.001$ ) and the BChl- $a$ fluorescence (Spearman correlation, $r=0.73, n=60, p<0.0001)$. AAP bacterial abundance and BChl- $a$ fluorescence were also positively correlated (Spearman correlation, $r=0.81, n=46, p<0.0001$ ).

AAP bacterial abundance ranged from $3.0 \times 10^{2}$ to $3.5 \times$ $10^{4}$ cells $\mathrm{ml}^{-1}$, accounting for 0.1 to $4 \%$ of total prokaryotic abundance. Although AAP bacteria were present at all stations within the first $150 \mathrm{~m}$ depth, their abundance varied along the longitudinal transect and with depth (Fig. 3a). AAP bacteria reached up to $3.5 \times 10^{4}$ cells $\mathrm{ml}^{-1}$ in the western part (station 21 at $50 \mathrm{~m}$ depth) whereas they did not exceed $9.0 \times 10^{2}$ cells $\mathrm{ml}^{-1}$ in the eastern part (station 9 at $50 \mathrm{~m}$ ). Abundances in the Ionian Basin (stations 1 and 13) were intermediate up to $1.9 \times 10^{4}$ cells $\mathrm{ml}^{-1}$. Relative abundance of AAP bacteria in subsurface waters did not vary substantially along the longitudinal transect, ranging from 0.4 to $0.9 \%$ of total prokaryote abundance. The relative abundance maxima were at or just above the DCM at all the stations, reaching up to $4 \%$ in the western part (station 21 at $50 \mathrm{~m}$ ) and less than $1 \%$ in the eastern part.

The depth of AAP bacterial abundance maxima deepened from west to east, as previously noticed for the maximum values of BChl- $a$ concentrations and the DCM. At stations 27 and 25 in the western basin, the DCM corresponded to the depth of highest AAP bacterial abundance, reaching 1.6 and
$2.8 \times 10^{4}$ AAP cells $\mathrm{ml}^{-1}$ at $30 \mathrm{~m}$ and $50 \mathrm{~m}$ depth, respectively. At station 21, the highest numbers of AAP bacteria were found just above the DCM at $50 \mathrm{~m}$, while at stations 13 and 9 AAP bacteria peaked at $60-70 \mathrm{~m}$ above the DCM (at $80 \mathrm{~m}$ and $50 \mathrm{~m}$ depth, respectively). The highest numbers of AAP bacteria were measured below the DCM at stations 1, 5 and 17 at $85 \mathrm{~m}, 110 \mathrm{~m}$ and $90 \mathrm{~m}$, respectively.

BChl- $a$ fluorescence in selected size fractions was examined at the same eight stations (Fig. 3b). The contribution of each size fraction was measured only at depths with the highest BChl- $a$ fluorescence. The $<0.8 \mu \mathrm{m}$ fraction containing free-living AAP bacteria accounted for generally most (64 to 93\%) of the total BChl- $a$ fluorescence. The only exception was station 1 where the particle-associated BChl- $a$ fluorescence in the $0.8-3 \mu \mathrm{m}$ and $>3 \mu \mathrm{m}$ fractions accounted for $87 \%$ and $77 \%$ of the total signal at $70 \mathrm{~m}$ and $85 \mathrm{~m}$, respectively.

\subsection{AAP bacteria, cyanobacteria and total prokaryotes}

The abundance of AAP bacteria was compared to that of the two main genera of photoautotrophic bacteria, including the cyanobacteria Prochlorococcus and Synechococcus and of total prokaryotes, including AAP bacteria (Fig. 4a).

At the three stations selected in the western basin (station 21), the Ionian basin (station 13) and the Levantine basin (station 9), total prokaryotes outnumbered cyanobacteria and AAP bacteria, with abundances ranging between 2.3 and $6.90 \times 10^{5}$ cells ml ${ }^{-1}$ (Fig. 4a). They were more abundant in the western than in the eastern part of the Mediterranean Sea, and in the subsurface than in deep waters. AAP cells were about 1.2-fold larger on average $( \pm 0.6)$ and up to 4-fold larger than cells in the total prokaryotes community (data not shown).

In surface waters (5 m) Synechococcus outnumbered AAP bacteria by 2- to 4-fold. In contrast, from 25 to $150 \mathrm{~m}$, AAP bacterial abundance was equal to or 9-fold higher than that of Synechococcus. Prochlorococcus cells were not detected by flow cytometry in surface waters at the three stations. However, Prochlorococcus was 2- to 22-fold more abundant than AAP bacteria at deeper depths at stations 13 and 9. In contrast, AAP bacteria abundances were in the same order of magnitude than that of Prochlorococcus at station 21, with values up to $4.0 \times 10^{4}$ cells $\mathrm{ml}^{-1}$.

\subsection{Photosynthetic pigment concentrations and cell quotas}

Photosynthetic pigments were compared at the same three stations (Fig. 4b). Total Chl- $a$ and Div-Chl- $a$ were up to 300-fold and 50-fold higher than BChl- $a$, respectively. DivChl- $a$ peaked at the DCM (51 to $82 \mathrm{ng} \mathrm{l}^{-1}$ ), while BChl- $a$ concentration was generally at its highest level just above the DCM and then decreased with depth. BChl- $a /$ Chl- $a$ ratio decreased with depth, from 1 to $1.5 \%$ to undetectable values 

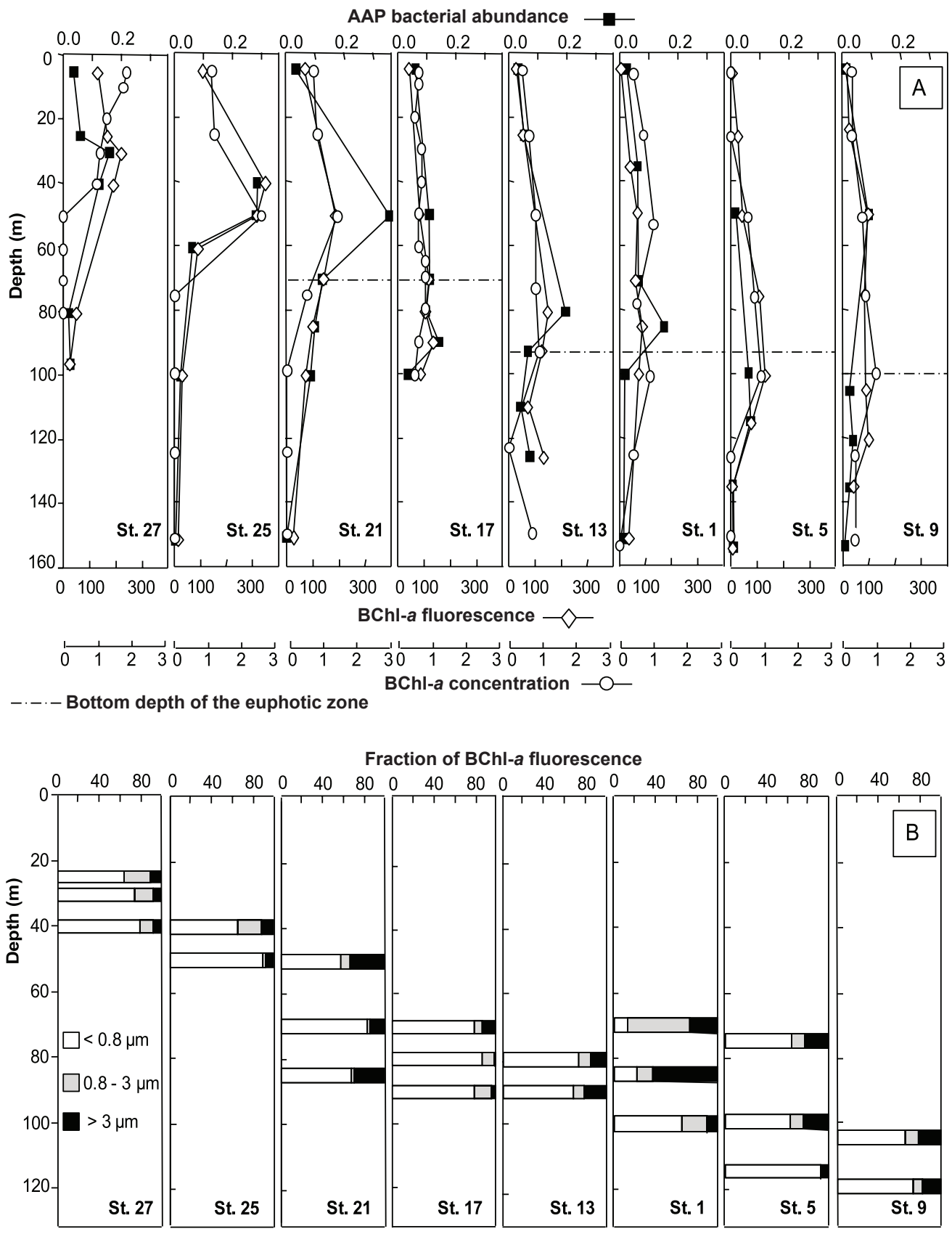

Fig. 3. Vertical profiles at 8 stations along the BOUM transect of (A) AAP bacterial abundance $\left(10^{5}\right.$ cells $\left.^{-1}\right)$, BChl- $a$ concentration (ng $\left.1^{-1}\right)$ and BChl- $a$ fluorescence (arbitrary units) and (B) size fractionation $(<0.8 \mu \mathrm{m}, 0.8-3 \mu \mathrm{m}$ and $>3 \mu \mathrm{m})$ of BChl- $a$ fluorescence (in $\%$ ). The bottom of the euphotic zone is the depth to which $1 \%$ of photosynthetically active radiation (PAR) reached. No PAR data were available at stations 25 and 27.

(Fig. 4c). The Div-Chl- $a$ content per Prochlorococcus cell increased with depth at all stations from undetectable values to $2.50 \mathrm{fg}$ cell $^{-1}$. The BChl- $a$ quota varied substantially along the transect (Fig. 4c). It decreased with depth and peaked at the bottom depth of the euphotic zone. This peak is more pronounced at stations 13 and 9 at 90 and $100 \mathrm{~m}$, respectively, than at station 21 at $70 \mathrm{~m}$. The BChl- $a$ quota reaching up to $0.44 \mathrm{fg} \mathrm{cell}^{-1}$ was highest at station 9 where a second peak occurred at $150 \mathrm{~m}$. The BChl- $a$ quota was significantly higher in the eastern basin (stations 1, 5 and 9) than in the central (stations 13 and 17, ANOVA, $p=0.007$, LSD pair-wised test, $p=0.005$ ) and the western (stations 21,25 and 27, LSD pair-wised test, $p=0.009$ ) basins. 

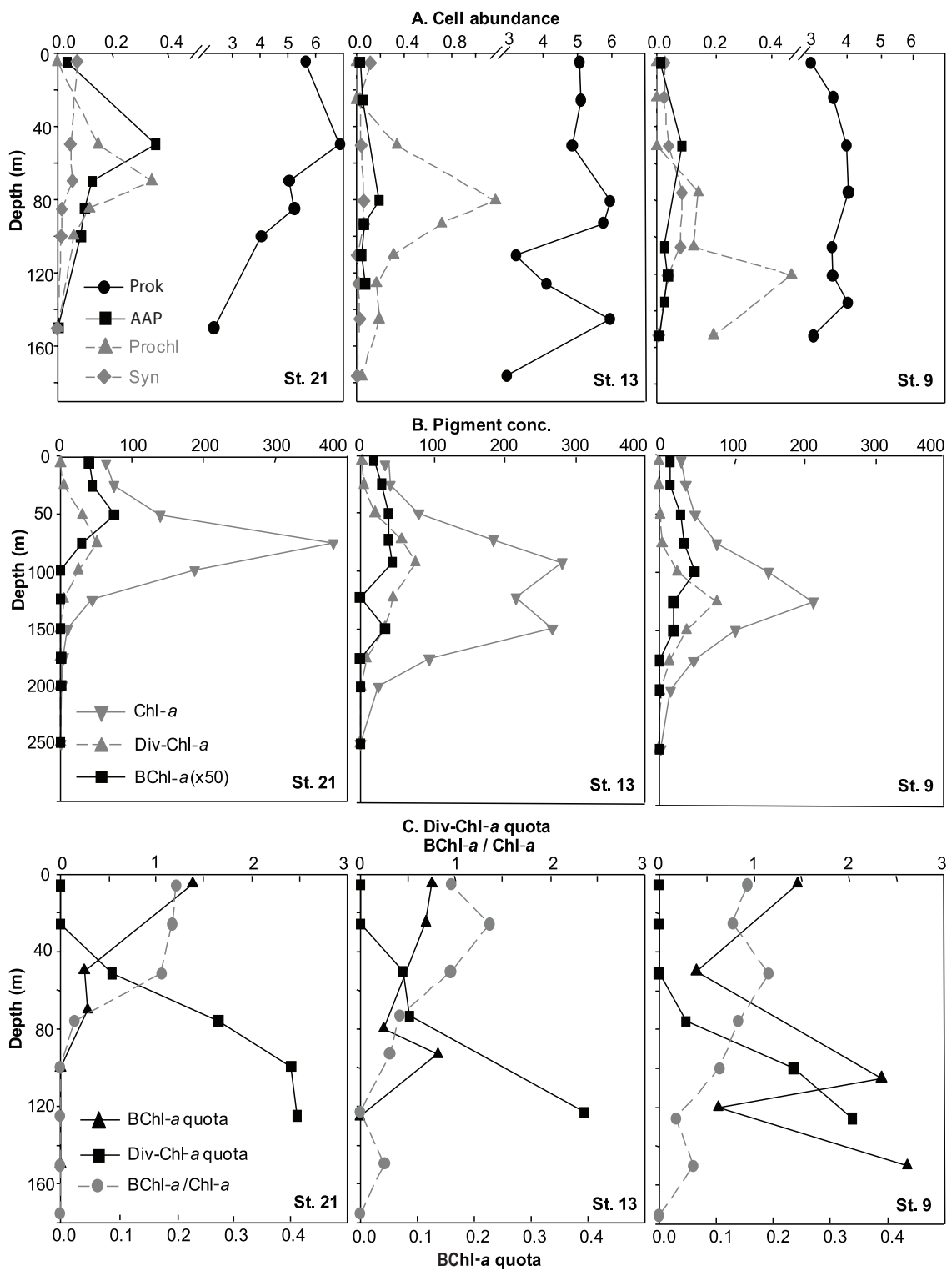

Fig. 4. Vertical profiles at stations 21, 13 and 9 of (A) total prokaryotes, AAP bacteria, Prochlorococcus and Synechococcus abundances $\left(10^{5}\right.$ cells ml $\left.{ }^{-1}\right),(\mathbf{B})$ Chl- $a$, Div-Chl- $a$ and BChl- $a$ concentrations $\left(\mathrm{ng}^{-1}\right)$ and $(\mathbf{C})$ Div-Chl- $a$ and BChl- $a$ content per cell (fg cell $\left.{ }^{-1}\right)$ and BChl- $a$ /Chl- $a$ ratios (\%).

\subsection{Relationship between AAP bacterial abundance and environmental factors}

The first two RDA axes explained $78 \%$ of the variability in the abundances of bacteria and cyanobacteria and $99 \%$ of the relationship between these abundances and the environmental variables (Fig. 5). The two first canonical axes were significant $(p=0.002)$. AAP bacteria appeared to be closely linked to the total prokaryotes and the autotrophic Synechococcus. There was a clear separation between the samples collected below the euphotic zone (black downtriangles, on the top-side) and those obtained in the euphotic zone (open up-triangles, on the bottom-side, Fig. 5), indicat- ing that depth and light availability were significant explanatory variables. Concentrations of Chl- $a$, nutrient and organic pools and the temperature and salinity appeared to be main factors accounting for the variation in AAP bacterial and total prokaryotic abundances with depth and longitude.

A multiple regression analysis indicated that concentrations of Chl- $a, \mathrm{NO}_{3}+\mathrm{NO}_{2}$ and DOC were the main parameters controlling AAP bacterial abundance. The combination of these three parameters explained $54 \%(p<0.0001)$ of the variability in AAP bacterial abundance. 
Table 1. Initial chemical conditions and biological parameters prevailing in surface (5 $\mathrm{m}$ depth) seawater samples before nutrient amendments.

\begin{tabular}{|c|c|c|c|c|}
\hline Parameter $^{1}$ & Station A & Station 17 & Station 9 & Station C \\
\hline $\mathrm{NO}_{3}+\mathrm{NO}_{2}(\mathrm{nM})$ & 40 & 20 & ld & $1 d^{2}$ \\
\hline $\mathrm{NH}_{4}(\mathrm{nM})$ & 4 & 3 & ld & 4 \\
\hline $\mathrm{PO}_{4}$ method $1 / \operatorname{method} 2^{3}(\mathrm{nM})$ & $10 / 6$ & $10 / 5$ & $1 d / 20$ & $60 / 14$ \\
\hline $\mathrm{DOC}(\mu \mathrm{M})$ & 66 & 59 & 71 & 70 \\
\hline $\mathrm{DON}(\mu \mathrm{M})$ & 4.9 & 5.1 & 4.4 & 4.9 \\
\hline $\mathrm{DOP}(\mu \mathrm{M})$ & 0.07 & 0.04 & 0.02 & 0.03 \\
\hline POC $(\mu \mathrm{M})$ & 4.5 & 5.0 & 3.2 & 2.7 \\
\hline $\mathrm{PON}(\mu \mathrm{M})$ & 0.37 & 0.41 & 0.23 & 0.37 \\
\hline POP $(\mu \mathrm{M})$ & 0.026 & 0.026 & 0.013 & 0.016 \\
\hline $\mathrm{PO}_{4}$ turnover time $(\mathrm{h})$ & 1.6 & 3.0 & 3.4 & 11.1 \\
\hline Chl- $a\left(\mu g 1^{-1}\right)$ & 0.06 & 0.06 & 0.03 & 0.03 \\
\hline BChl- $a\left(n g 1^{-1}\right)$ & $<2$ & 6 & 3 & $<2$ \\
\hline Bacterial abundance $\left(\times 10^{5}\right.$ cells ml $\left.{ }^{-1}\right)$ & 4.43 & 5.51 & 2.69 & 2.51 \\
\hline AAP bacterial abundance $\left(\times 10^{4}\right.$ cells $\left.\mathrm{ml}^{-1}\right)$ & nd & 0.63 & 0.12 & nd \\
\hline Bacterial production $\left(\mathrm{ngCl}^{-1} \mathrm{~h}^{-1}\right)$ & 26 & 33 & 12 & 12 \\
\hline
\end{tabular}

\footnotetext{
${ }^{1}$ See in the text for the meaning of the abbreviations.

$2 \mathrm{ld}=$ below the detection limit (see Material and methods).

${ }^{3}$ In method $1(\mathrm{ld}=10 \mathrm{nM})$, phosphate was analysed on board using the automated colorimetric technique (Tréguer and Le Corre, 1975; Wood et al., 1967).

In method $2(\mathrm{ld}=2 \mathrm{nM})$, phosphate was analysed on board using the MAGIC method (Rimmelin and Moutin, 2005).
}

\subsection{Effects of nutrient and glucose amendments on bacterial production and growth of AAP bacteria and total prokaryotes}

In surface waters, nutrient $\left(\mathrm{NO}_{3}+\mathrm{NO}_{2}, \mathrm{NH}_{4}\right.$ and $\left.\mathrm{PO}_{4}\right)$ concentrations were initially close or below the detection limit (Table 1). $\mathrm{PO}_{4}$ turnover time is the most broadly-applicable measurement of $\mathrm{PO}_{4}$ availability because it has the potential to identify variations in $\mathrm{P}$ availability even when $\mathrm{PO}_{4}$ concentrations become analytically undetectable (Moutin et al., 2002, 2008). Turnover times of phosphate in surface waters were very short at the four stations. This rapid turnover, along with very low concentrations, indicated that microbial communities experienced conditions where phosphate was scarce. Concentrations of Chl- $a$, POP and POC, abundance of prokaryotes and bacterial production were significantly lower in stations 9 and $\mathrm{C}$ than in stations 17 and $\mathrm{A}$, reflecting the west-east gradient in oligotrophy.

After amendments, bacterial production significantly increased in all P, N and NPC enrichments, the latter always stimulating production the most by 6 to 75 -fold relative to the control (Table 2). A strong positive effect of glucose on bacterial production (15-fold relative to the control) was only observed at station C. As previously noticed by Van Wambeke et al. (2008), bacterial abundance always increased less than bacterial production. Significant increases in prokaryotic abundance were observed in $\mathrm{N}$ amended bottles at station $\mathrm{C}$ (2-fold) and in NPC enrichments at both analyzed stations (2- and 6-fold at stations 9 and $\mathrm{C}$, respectively).

The intensity of the AAP bacterial growth response generally differed from that of the total prokaryote growth re- sponse at the stations they could be compared (stations C and 9). The main differences were the stronger increase after $\mathrm{N}$ and $\mathrm{C}$ additions for AAP bacteria compared with the total community. In contrast to the positive effect on bacterial production at all stations, the $\mathrm{P}$ addition only weakly stimulated net AAP bacterial and prokaryote growths at station 9 .

\section{Discussion}

Our study is the first to investigate the biogeographical patterns of AAP bacteria in the Mediterranean Sea by IR fluorometry, epifluorescence microscopy and HPLC pigment analysis. Few studies have used all these methods together (Kolber et al., 2001; Lami et al., 2009). In this study, we found significant correlations between AAP bacterial abundance, BChl- $a$ fluorescence and concentrations revealing new insights in the distribution and controls of AAP bacteria.

The fine spatial scale resolution obtained with measurement of BChl- $a$ concentrations, hitherto never shown in other studies, provides a comprehensive picture of biogeographical trends of AAP bacteria along different trophic regimes. The values (up to $3.1 \mathrm{ng} \mathrm{l}^{-1}$ ) are consistent with other studies of oligotrophic environments (Cottrell et al., 2006; Kolber et al., 2001; Schwalbach and Fuhrman, 2005; Sieracki et al., 2006). Both AAP bacterial abundance and BChl- $a$ concentrations significantly decreased with increasing longitude and oligotrophy from west to east, though both varied less with location than with depth. Kolber et al. (2000) suggested that phototrophy would give AAP bacteria a competitive advantage over non-phototrophic bacteria when nutrient sources 
Table 2. Bacterial production, abundances of total prokaryotes and AAP bacteria after nutrient ( $\mathrm{P}$ for phosphate, $\mathrm{N}$ for nitrogen, $\mathrm{C}$ for glucose and NPC for $\mathrm{N}+\mathrm{P}+\mathrm{C}$ ) amendments of surface ( $5 \mathrm{~m}$ depth) seawater samples at 4 stations (St.) of the BOUM transect. Results are expressed relative to the unamended controls.

\begin{tabular}{lllll|llll|lllll}
\hline & \multicolumn{4}{c}{ Bacterial Production } & \multicolumn{4}{c}{ Total prokaryotes } & \multicolumn{4}{c}{ AAP bacteria } \\
& P & N & C & NPC & P & N & C & NPC & P & N & C & NPC \\
\hline St. A & 1.7 & 2.2 & 1.1 & 32.8 & nd* & nd & nd & nd & 1.4 & 1.8 & 1.7 & 3.2 \\
St. 17 & 1.8 & 1.9 & 1.3 & 6.9 & nd & nd & nd & nd & 1.3 & 1.6 & 1.2 & 3.1 \\
St. 9 & 3.5 & 2.0 & 1.2 & 18.7 & 1.3 & 1.1 & 1.1 & 2.1 & 1.1 & 4.6 & 2.4 & 4.6 \\
St. C & 2.4 & 10.6 & 15.0 & 75.5 & 0.9 & 2.0 & 1.1 & 5.9 & 1.0 & 2.4 & 1.9 & 3.8 \\
\hline
\end{tabular}

*nd: not determined

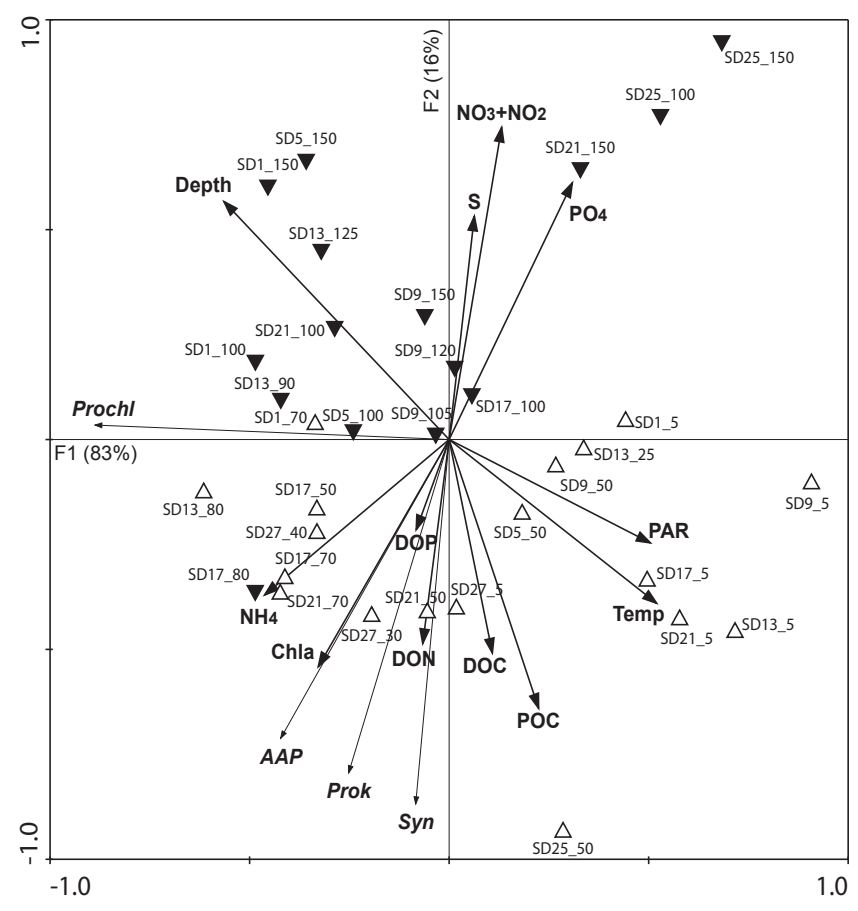

Fig. 5. Redundancy analysis using the abundances of AAP bacteria (AAP), total prokaryotes (Prok), Prochlorococcus (Prochl) and Synechococcus (Syn) as dependent variables (thin arrows) and temperature (Temp), salinity (S), depth, photosynthetically active radiation (PAR), concentrations of Chl- $a$ (Chl- $a)$, nitrite + nitrate $\left(\mathrm{NO}_{2}\right.$ $\left.+\mathrm{NO}_{3}\right)$, phosphate $\left(\mathrm{PO}_{4}\right)$, ammonium $\left(\mathrm{NH}_{4}\right)$, dissolved organic carbon (DOC), nitrogen (DON) and phosphorous (DOP) and particulate organic carbon (POC) as explanatory variables (thick arrows). The samples are identified as "below the euphotic zone" (black down-triangles) or "euphotic zone" (open up-triangles) samples. In the name of the samples, the first number corresponds to the number of the sampling station and the second number to the sampling depth.

are scarce. Consistent with a global ocean study (Jiao et al., 2007), our data showed the opposite pattern as the maximum AAP bacteria abundance was positively related with the concentration of Chl- $a$. Similarly, no clear link between AAP bacterial abundance and oligotrophy was established since abundances of AAP bacteria can be high in estuarine, coastal and shelf waters (e.g. Cottrell et al., 2010; Waidner and Kirchman, 2007). AAP bacteria were found to be more abundant in the upper layers of the photic zone than below the sunlit layers of the water column of the Mediterranean Sea. Other studies also reported that AAP bacteria are major bacterial components in the photic zone, in agreement with their phototrophic abilities (Cottrell et al., 2006; Kolber et al., 2001).

Our statistical analyses indicated a strong positive correlation between AAP bacteria and various indices of organic matter supply, suggesting that AAP bacteria were more abundant when organic carbon was available. Furthermore, their abundance and BChl- $a$ concentrations were highest in the western basin which is a bit richer in nutrients (Pujo-Pay et al., 2011) and in phytoplankton-derived organic material (López-Sandoval et al., 2011) than the eastern basin. The distribution of AAP bacteria may be determined by the availability of specific organic compounds provided by phytoplankton (Jiao et al., 2007). Consistent with the net increase of their abundance after glucose additions in most stations, this supports the view that AAP bacteria represent a physiological group of photoheterotrophs able to use light-derived energy to rapidly grow when organic carbon sources are available. This is in agreement with their high abundances in estuarine waters (Schwalbach and Fuhrman, 2005; Waidner and Kirchman, 2007) and their common association with phytoplankton blooms (Gonzalez et al., 2000; Suzuki et al., 2001).

It has been shown that AAP bacteria are mainly freeliving in surface offshore Mediterranean waters and that a large fraction $(50 \%)$ can be attached to particles at the DCM (Lami et al., 2009). By examining the distribution of particleattached and free-living BChl- $a$ fluorescence on a larger dataset, we found that the majority of AAP bacteria living at the DCM of Mediterranean waters were free-living cells. This supports the view that this free-living lifestyle may reflect cellular and physiological adaptations to oligotrophic waters (Cottrell et al., 2010), with a low and intermittent supply of dissolved substrates. 
Our data on BChl- $a$ and Div-Chl- $a$ can be used to further explore the importance of phototrophy in AAP bacteria in this part of the Mediterranean Sea. The concentrations of BChl- $a$ per AAP cell in the eastern basin of the Mediterranean Sea was 4- to 16-fold lower than the DivChl- $a$ content per Prochlorococcus cell. This may suggest that phototrophy was probably a lower part of the AAP cell metabolism when compared to Prochlorococcus, which mainly relies on phototrophy. However, the BChl- $a$ quotas reached notably high values along the transect. These values are up to 2.5-fold higher than the values observed in the oligotrophic South Pacific Ocean (Lami et al., 2007), 3-fold higher than those observed in the Sargasso Sea (Sieracki et al., 2006) and until 10-fold higher than those observed in the Mid-Atlantic Bight (Cottrell et al., 2006). Nutrients and Chl$a$ concentrations measured during the BOUM cruise suggest that the oligotrophic conditions experienced by AAP bacteria during the stratification period of the Mediterranean Sea were more severe than that observed in the three latter oligotrophic regions. Moreover, the BChl- $a$ content per cell was significantly higher in the ultra-oligotrophic eastern basin than in the two other basins. Assuming that BChl- $a$ quotas indicate the extent of phototrophic potential (Cottrell et al., 2006), our data suggest that reliance on phototrophy varied along the oligotrophic gradient and that nutrient and/or carbon limitation favors BChl- $a$ synthesis in natural communities as it has been reported for AAP cultures (Koblížek et al., 2003; Yurkov and Csotonyi, 2009).

In the Mediterranean Sea, which is one of the world's most oligotrophic bodies of water, inorganic nutrients and particularly phosphate $(\mathrm{P})$ have been shown to limit both phytoplankton and bacteria in certain areas during stratification (Pinhassi et al., 2006; Thingstad et al., 1998; Van Wambeke et al., 2002). Despite unusual high phosphate concentrations at station $\mathrm{C}$, in situ chemical concentrations indicated more stringent oligotrophic conditions in the eastern basin than in the western basin (Pujo-Pay et al., 2011). It has been hypothesized that the capacity of AAP bacteria to generate energy from light could reduce the metabolic requirements for recycling the organic carbon resources (Cho et al., 2007). Mašín et al. (2008) suggested that light-generated energy could enhance $\mathrm{P}$ acquisition in $\mathrm{P}$-depleted environments. On the basis of our nutrient-addition experiments, we cannot speculate about P-limitation of AAP bacteria since growth of AAP and total prokaryotes were not stimulated by $\mathrm{P}$ addition, although higher heterotrophic bacterial activity was observed. Consistent with our results, Tanaka et al. (2011) did not find any indication of P-alone limitation although a clear P-starved status in the Mediterranean basins was observed. Moreover, we observed that net growth of AAP bacteria was enhanced by glucose and nitrogen additions in the eastern basin whereas net growth of total prokaryotes was not stimulated by these additions. This result does not favor the hypothesis that lightderived energy could serve for supporting the nutrient acquisition in a nutrient-depleted environment. The problem may be in trying to deduce the impact of the additions by measuring net growth, which is a function of the bacterial response and mortality factors. However, AAP bacteria and total prokaryotes responded differently in terms of net variation of their abundances, which suggest different growth and mortality controls between these two populations.

\section{Conclusions}

Our study gives a comprehensive picture of the longitudinal and vertical distribution of AAP bacteria in the Mediterranean Sea. AAP bacteria were more abundant in the euphotic zone than in deeper waters and in the western than in the eastern basin of the Mediterranean Sea. As a significant part of the total bacterial abundance, AAP bacteria abundances decreased with the increasing oligotrophic gradient from the western to the eastern basin of the Mediterranean Sea. The simultaneous measurements of BChl- $a$ fluorescence, pigment concentration and AAP cell abundance examined along with some environmental parameters support the notion of the prominence of the heterotrophic metabolism in AAP bacteria. However, the high BChl- $a$ quotas observed in the samples from the ultra-oligotrophic eastern basin suggest that their phototrophic lifestyle may be especially advantageous under nutrient- and carbon-depleted environmental conditions. Assessing the impact of photoheterotrophy in aquatic systems will be needed to better understand the role of this functional group into elemental cycling.

Acknowledgements. This is a contribution of the BOUM (Biogeochemistry from the Oligotrophic to the Ultraoligotrophic Mediterranean) experiment (http://www.com.univ-mrs.fr/BOUM/) of the french national LEFE-CYBER program, the european IP SESAME and the international IMBER project. The BOUM experiment was coordinated by the Institut des Sciences de l'Univers (INSU) and managed by the Centre National de la Recherche Scientifique (CNRS). The authors thank the crew of the R/V L'Atalante for outstanding shipboard operation and the scientists from the BOUM cruise for helpful contribution at sea. Claudie Marec and Louis Prieur are warmly thanked for their efficient help in CTD rosette management and data processing. We also thank Romain Mauriac and Agathe Talarmin for measurement of DIP turnover time and Claude Courties for his contribution to the flow cytometry analyses. We wish to thank Thierry Moutin for coordinating the BOUM cruise and inviting us onboard. We are grateful to Michal Koblížek for his help with detection of AAP bacterial colonies using the infra-red system available in his laboratory. Thanks are also due to two reviewers for useful comments on the manuscript. This work was financially supported by the Pierre Fabre-UPMC-CNRS join research team (EMR) at the Observatoire Océanologique de Banyuls-sur-mer (OBB) and by the program LEFE-CYBER PANAME (CNRS-INSU). MTC and DLK were supported by NSF grant MCB-0453993. DL was supported by the EMR at the OBB and OD was supported by a grant from the Ministry of Higher Education and Research.

Edited by: T. Moutin 


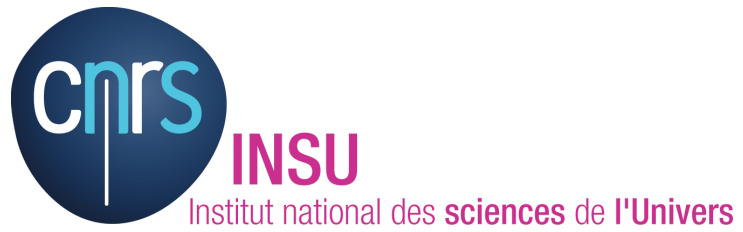

The publication of this article is financed by CNRS-INSU.

\section{References}

Beatty, J. T.: On the natural selection and evolution of the aerobic phototrophic bacteria, Photosynth. Res., 73, 109-114, 2002.

Bendschneider, K. and Robinson, R. J.: A new spectrophotometric determination of nitrite in seawater, J. Mar. Res., 11, 87-96, 1952.

Benner, R. and Strom, M.: A critical-evaluation of the analytical blank associated with DOC measurements by high-temperature catalytic-oxidation, Mar. Chem., 41, 153-160, 1993.

Berman, T., Walline, P. D., Schneller, A., Rothenberg, J., and Towsend, D. W.: Secchi disk depth record: a claim for the eastern Mediterranean, Limnol. Oceanogr., 30, 447-448, 1985.

Cho, J. C., Stapels, M. D., Morris, R. M., Vergin, K. L., Schwalbach, M. S., Givan, S. A., Barofsky, D. F., and Giovannoni, S. J.: Polyphyletic photosynthetic reaction centre genes in oligotrophic marine Gammaproteobacteria, Environ. Microbiol., 9, 1456-1463, 2007.

Cottrell, M. T. and Kirchman, D. L.: Photoheterotrophic microbes in the Arctic Ocean in summer and winter, Appl. Environ. Microbiol., 75, 4958-4966, 2009.

Cottrell, M. T., Mannino, A., and Kirchman, D. L.: Aerobic anoxygenic phototrophic bacteria in the Mid-Atlantic Bight and the North Pacific Gyre, Appl. Environ. Microbiol., 72, 557-564, 2006.

Cottrell, M. T., Ras, J., and Kirchman, D. L.: Bacteriochlorophyll and community structure of aerobic anoxygenic phototrophic bacteria in a particle-rich estuary, ISME J., 4, 945-954, 2010.

Crombet, Y., Leblanc, K., Quéguiner, B., Moutin, T., Rimmelin, P., Ras, J., Claustre, H., Leblond, N., Oriol, L., and Pujo-Pay, M.: Deep silicon maxima in the stratified oligotrophic Mediterranean Sea, Biogeosciences, 8, 459-475, doi:10.5194/bg-8-4592011, 2011.

De Corte, D., Yokokawa, T., Varela, M. M., Agogue, H., and Herndl, G. J.: Spatial distribution of bacteria and Archaea and amoA gene copy numbers throughout the water column of the eastern Mediterranean Sea, ISME J., 3, 147-158, 2009.

Eiler, A.: Evidence for the ubiquity of mixotrophic bacteria in the upper ocean: Implications and consequences, Appl. Environ. Microbiol., 72, 7431-7437, 2006.

Gonzalez, J. M., Simo, R., Massana, R., Covert, J. S., Casamayor, E. O., Pedros-Alio, C., and Moran, M. A.: Bacterial community structure associated with a dimethylsulfoniopropionate producing North Atlantic algal bloom, Appl. Environ. Microbiol., 66, 4237-4246, 2000.

Holmes, M. R., Aminot, A., Kérouel, R., Hooker, B. A., and Peterson, B. J.: A simple and precise method for measuring ammonium in marine and freshwater ecosystems, Can. J. Fish. Aquat. Sci., 56, 1801-1808, 1999.
Ignatiades, L.: Scaling the trophic status of the Aegean Sea, eastern Mediterranean, J. Sea Res., 54, 51-57, 2005.

Jeanthon, C., Boeuf, D., Dahan, O., Le Gall, F., Garczarek, L., Bendif, E. M., and Lehours, A.-C.: Diversity of cultivated and metabolically active aerobic anoxygenic phototrophic bacteria along an oligotrophic gradient in the Mediterranean Sea, Biogeosciences Discuss., in preparation, 2011.

Jiao, N., Zhang, Y., Zeng, Y. H., Hong, N., Liu, R., Chen, F., and Wang, P.: Distinct distribution pattern of abundance and diversity of aerobic anoxygenic phototrophic bacteria in the global ocean, Environ. Microbiol., 9, 3091-3099, 2007.

Karl, D. M.: Microbiological oceanography - Hidden in a sea of microbes, Nature, 415, 590-591, 2002.

Karl, D. M. and Tien, G.: MAGIC: a sensitive and precise method for measuring dissolved phosphorus in aquatic environment, Limnol. Oceanogr., 37, 105-116, 1992.

Koblížek, M., Béjà, O., Bidigare, R. R., Christensen, S., BenitezNelson, B., Vetriani, C., Kolber, M. K., Falkowski, P. G., and Kolber, Z. S.: Isolation and characterization of Erythrobacter sp strains from the upper ocean, Arch. Microbiol., 180, 327-338, 2003.

Koblížek, M., Stoń-Egiert, J., Sagan, S., and Kolber, Z. S.: Diel changes in bacteriochlorophyll a concentration suggest rapid bacterioplankton cycling in the Baltic Sea, FEMS Microbiol. Ecol., 51, 353-361, 2005.

Koblížek, M., Falkowski, P. G., and Kolber, Z. S.: Diversity and distribution of photosynthetic bacteria in the Black Sea, DeepSea Res. Pt. II, 53, 1934-1944, 2006.

Koblížek, M., Mašín, M., Ras, J., Poulton, A. J., and Prášil, O.: Rapid growth rates of aerobic anoxygenic phototrophs in the ocean, Environ. Microbiol., 9, 2401-2406, 2007.

Kolber, Z. S., Van Dover, C. L., Niederman, R. A., and Falkowski, P. G.: Bacterial photosynthesis in surface waters of the open ocean, Nature, 407, 177-179, 2000.

Kolber, Z. S., Plumley, F. G., Lang, A. S., Beatty, J. T., Blankenship, R. E., VanDover, C. L., Vetriani, C., Koblížek, M., Rathgeber, C., and Falkowski, P. G.: Contribution of aerobic photoheterotrophic bacteria to the carbon cycle in the ocean, Science, 292, 24922495, 2001.

Lamy, D., De Carvalho-Maalouf, P., Cottrell, M. T., Lami, R., Catala, P., Oriol, L., Caparros, J., Ras, J., Kirchman, D. L., and Lebaron, P.: Seasonal dynamics of aerobic phototrophs in a Mediterranean coastal lagoon, Aquat. Microb. Ecol., 62, 153163, 2011.

Lami, R., Cottrell, M. T., Ras, J., Ulloa, O., Obernosterer, I., Claustre, H., Kirchman, D. L., and Lebaron, P.: High abundances of aerobic anoxygenic photosynthetic bacteria in the South Pacific Ocean, Appl. Environ. Microbiol., 73, 4198-4205, 2007.

Lami, R., Euperová, Z., Ras, J., Lebaron, P., and Koblížek, M.: Distribution of free-living and particle-attached aerobic anoxygenic phototrophic bacteria in marine environments, Aquat. Microb. Ecol., 55, 31-38, 2009.

Lehours, A.-C., Cottrell, M. T., Dahan, O., Kirchman, D. L., and Jeanthon, C.: Summer distribution and diversity of aerobic anoxygenic phototrophic bacteria in the Mediterranean Sea in relation to environmental variables, FEMS Microbiol. Ecol., 74, 397-409, 2010.

López-Sandoval, D. C., Fernández, A., and Marañón, E.: Dissolved and particulate primary production along a longitudinal 
gradient in the Mediterranean Sea, Biogeosciences, 8, 815-825, doi:10.5194/bg-8-815-2011, 2011.

Marie, D., Simon, N., Guillou, L., Partensky, F., and Vaulot, D.: Flow cytometric analysis of marine picoplankton, in: Protocols in flow cytometry and cell sorting, edited by: Diamond, R. A. and De Maggio, S., Springer-Verlag, Berlin, Germany, 421-454, 2002.

Mašín, M., Nedoma, J., Pechar, L., and Koblížek, M.: Distribution of aerobic anoxygenic phototrophs in temperate freshwater systems, Environ. Microbiol., 10, 1988-1996, 2008.

Moran, M. A. and Miller, W. L.: Resourceful heterotrophs make the most of light in the coastal ocean, Nat. Rev. Microbiol., 5, 792-800, 2007

Moutin, T. and Raimbault, P.: Primary production, carbon export and nutrients availability in western and eastern Mediterranean Sea in early summer 1996 (MINOS cruise), J. Marine Syst., 3334, 273-288, 2002.

Moutin, T., Thingstad, T. F., Van Wambeke, F., Marie, D., Slawyk, G., Raimbault, P., and Claustre, H.: Does competition for nanomolar phosphate supply explain the predominance of the cyanobacterium Synechococcus?, Limnol. Oceanogr., 47, 15621567, 2002.

Moutin, T., Karl, D. M., Duhamel, S., Rimmelin, P., Raimbault, P., Van Mooy, B. A. S., and Claustre, H.: Phosphate availability and the ultimate control of new nitrogen input by nitrogen fixation in the tropical Pacific Ocean, Biogeosciences, 5, 95-109, doi:10.5194/bg-5-95-2008, 2008.

Moutin, T., Van Wambeke, F., and Prieur, L.: Introduction to the Biogeochemistry from the Oligotrophic to the Ultraoligotrophic Mediterranean (BOUM) experiment, Biogeosciences Discuss., in preparation, 2011.

Murphy, J. and Riley, J. P.: A modified single solution method for the determination of phosphate in natural waters, Anal. Chim. Acta, 27, 31-36, 1962.

Oz, A., Sabehi, G., Koblížek, M., Massana, R., and Béjà, O.: Roseobacter-like bacteria in Red and Mediterranean Sea aerobic anoxygenic photosynthetic populations, Appl. Environ. Microbiol., 71, 344-353, 2005.

Pinhassi, J., Gomez-Consarnau, L., Alonso-Saez, L., Sala, M. M., Vidal, M., Pedros-Alio, C., and Gasol, J. M.: Seasonal changes in bacterioplankton nutrient limitation and their effects on bacterial community composition in the NW Mediterranean Sea, Aquat. Microb. Ecol., 44, 241-252, 2006.

Pregl, F.: Quantitative Organic Microanalysis, Churchill, London, 69 pp., 1937.

Pujo-Pay, M. and Raimbault, P.: Improvement of the wet-oxydation procedure for simultaneous determination of particulate organic nitrogen and phosphorus collected on filters, Mar. Ecol.-Prog. Ser., 105, 203-207, 1994.

Pujo-Pay, M., Conan, P., and Raimbault, P.: Excretion of dissolved organic nitrogen by phytoplankton assessed by wet oxidation and N-15 tracer procedures, Mar. Ecol.-Prog. Ser., 153, 99-111, 1997.

Pujo-Pay, M., Conan, P., Oriol, L., Cornet-Barthaux, V., Falco, C., Ghiglione, J.-F., Goyet, C., Moutin, T., and Prieur, L.: Integrated survey of elemental stoichiometry $(\mathrm{C}, \mathrm{N}, \mathrm{P})$ from the western to eastern Mediterranean Sea, Biogeosciences, 8, 883899, doi:10.5194/bg-8-883-2011, 2011.
Ramette, A.: Multivariate analyses in microbial ecology, FEMS Microbiol. Ecol., 62, 142-160, 2007.

Ras, J., Claustre, H., and Uitz, J.: Spatial variability of phytoplankton pigment distributions in the Subtropical South Pacific Ocean: comparison between in situ and predicted data, Biogeosciences, 5, 353-369, doi:10.5194/bg-5-353-2008, 2008.

Rimmelin, P. and Moutin, T.: Re-examination of the MGIC method to determine low orthophosphate concentration in seawater, Anal. Chim. Acta, 548, 174-182, 2005.

Salka, I., Moulisová, V., Koblížek, M., Jost, G., Jürgens, K., and Labrenz, M.: Abundance, depth distribution, and composition of aerobic bacteriochlorophyll a-producing bacteria in four basins of the central Baltic Sea, Appl. Environ. Microbiol., 74, 43984404, 2008.

Schwalbach, M. S. and Fuhrman, J. A.: Wide-ranging abundances of aerobic anoxygenic phototrophic bacteria in the world ocean revealed by epifluorescence microscopy and quantitative PCR, Limnol. Oceanogr., 50, 620-628, 2005.

Sharp, J. H.: Improved analysis for particulate organic carbon and nitrogen from seawater, Limnol. Oceanogr., 19, 984-989, 1974.

Shiba, T.: Roseobacter litoralis gen. nov., sp. nov., and Roseobacter denitrificans sp. nov., aerobic pink-pigmented bacteria which contain bacteriochlorophyll- $a$, Syst. Appl. Microbiol., 14, 140145, 1991.

Sieracki, M. E., Gilg, I. C., Thier, E. C., Poulton, N. J., and Goericke, R.: Distribution of planktonic aerobic anoxygenic photoheterotrophic bacteria in the northwest Atlantic, Limnol. Oceanogr., 51, 38-46, 2006.

Smith, D. C. and Azam, F.: A simple and economical method for measuring bacterial protein synthesis rates in seawater using $3 \mathrm{H}-$ leucine, Mar. Microb. Food Webs, 6, 107-114, 1992.

Suzuki, M. T. and Béjà, O.: An elusive marine photosynthetic bacterium is finally unveiled, P. Natl. Acad. Sci. USA, 104, 25612562, 2007.

Suzuki, M. T., Preston, C. M., Chavez, F. P., and DeLong, E. F.: Quantitative mapping of bacterioplankton populations in seawater: field tests across an upwelling plume in Monterey Bay, Aquat. Microb. Ecol., 24, 117-127, 2001.

Tanaka, T., Thingstad, T. F., Christaki, U., Colombet, J., CornetBarthaux, V., Courties, C., Grattepanche, J.-D., Lagaria, A., Nedoma, J., Oriol, L., Psarra, S., Pujo-Pay, M., and Van Wambeke, F.: Lack of P-limitation of phytoplankton and heterotrophic prokaryotes in surface waters of three anticyclonic eddies in the stratified Mediterranean Sea, Biogeosciences, 8, 525-538, doi:10.5194/bg-8-525-2011, 2011.

ter Braak, C. J. and Smilauer, P.: CANOCO reference manual and CanoDraw for Wimdows user's guide: software for canonical community ordination (version 4.5), Microcomputer Power, Ithaca, NY, 500 pp., 2002.

ter Braak, C. J. F.: CANOCO - an extension of DECORANA to analyze species-environment relationships, Hydrobiologia, 184, 169-170, 1989.

Thingstad, T. F., Zweifel, U. L., and Rassoulzadegan, F.: P limitation of heterotrophic bacteria and phytoplankton in the northwest Mediterranean, Limnol. Oceanogr., 43, 88-94, 1998.

Tréguer, P. and Le Corre, P.: Manuel d'analyse des sels nutritifs dans l'eau de mer, in: Utilisation de l'Autoanalyzer II Technicon, 2nd edn., edited by: Laboratoire d'Océanographie chimique, U. d. B. O., Brest, France, 110 pp., 1975. 
Van Heukelem, L. and Thomas, C. S.: Computer-assisted highperformance liquid chromatography method development with applications to the isolation and analysis of phytoplankton pigments, J. Chromatogr., 910, 31-49, 2001.

Van Wambeke, F., Christaki, U., Giannokourou, A., Moutin, T., and Souvemerzoglou, K.: Longitudinal and vertical trends of bacterial limitation by phosphorus and carbon in the Mediterranean Sea, Microb. Ecol., 43, 119-133, doi:10.1007/s00248-001-00384, 2002.

Van Wambeke, F., Nedoma, J., Duhamel, S., and Lebaron, P.: Alkaline phosphatase activity of marine bacteria studied with ELF 97 substrate: success and limits in the P-limited Mediterranean Sea, Aquat. Microb. Ecol., 52, 245-251, 2008.

Van Wambeke, F., Catala, P., and Lebaron, P.: Relationships between cytometric characteristics of high and low nucleicacid bacterioplankton cells, bacterial production and environmental parameters along a longitudinal gradient across the Mediterranean Sea, Biogeosciences Discuss., 7, 8245-8279, doi:10.5194/bgd-7-8245-2010, 2010.

Waidner, L. A. and Kirchman, D. L.: Aerobic anoxygenic phototrophic bacteria attached to particles in turbid waters of the Delaware and Chesapeake estuaries, Appl. Environ. Microbiol., 73, 3936-3944, 2007.

Winter, C., Kerros, M. E., and Weinbauer, M. G.: Seasonal changes of bacterial and archaeal communities in the dark ocean: evidence from the Mediterranean Sea, Limnol. Oceanogr., 54, 160$170,2009$.
Wood, E. D., Amstrong, F. A. J., and Richards, F. A.: Determination of nitrate in sea water by cadmium-copper reduction to nitrite, $\mathrm{J}$. Mar. Biol. Assoc. UK, 47, 23-31, 1967.

Yurkov, V. V. and Beatty, J. T.: Aerobic anoxygenic phototrophic bacteria, Microbiol. Mol. Biol. Rev., 62, 695-724, 1998.

Yurkov, V. V. and Csotonyi, J. T.: New light on aerobic anoxygenic phototrophs, Adv. Photosynth. Respir., 28, 31-55, 2009.

Yutin, N. and Béjà, O.: Putative novel photosynthetic reaction centre organizations in marine aerobic anoxygenic photosynthetic bacteria: insights from metagenomics and environmental genomics, Environ. Microbiol., 7, 2027-2033, 2005.

Yutin, N., Suzuki, M. T., Teeling, H., Weber, M., Venter, J. C., Rusch, D. B., and Béjà, O.: Assessing diversity and biogeography of aerobic anoxygenic phototrophic bacteria in surface waters of the Atlantic and Pacific Oceans using the Global Ocean Sampling expedition metagenomes, Environ. Microbiol., 9, 1464-1475, 2007.

Yutin, N., Béjà, O., and Suzuki, M. T.: The use of denaturing gradient gel electrophoresis with fully degenerate pufM primers to monitor aerobic anoxygenic phototrophic assemblages, Limnol. Oceanogr.-Meth., 6, 427-440, 2008. 